\title{
KARAKTERISTIK GEMPABUMI DI SESAR MATANO MENGGUNAKAN ANALISIS ENERGI KUMULATIF DAN PERIODE ULANG
}

\author{
Indah Kurniawati ${ }^{*}$, Aldilla Damayanti Purnama Ratri ${ }^{2}$, Tomy Gunawan ${ }^{2}$ \\ ${ }^{1}$ Balai Besar Meteorologi Klimatologi dan Geofisika Wilayah IV Makassar \\ ${ }^{2}$ Balai Besar Meteorologi Klimatologi dan Geofisika Wilayah III Denpasar \\ * Corresponding author. Email: indah.kurniawati@bmkg.go.id
}

Manuscript received: 1 January 2020*); Received in revised form: 5 April 2020; Accepted: 8 April 2020

\begin{abstract}
Abstrak
Aktifitas seismik Sesar Matano sangat tinggi di mana gempabumi sering dirasakan masyarakat dan mengakibatkan kerusakan di area sekitarnya. Identifikasi aktifitas gempabumi dengan mengetahui besarnya energi yang dilepaskan di 6 segmen pada Sesar Matano diperlukan untuk perencanaan mitigasi gempabumi. Dilakukan juga estimasi periode ulang gempabumi yang akan terjadi disertai kemungkinan energi yang akan dilepaskan oleh gempabumi di masa yang akan datang. Data yang digunakan adalah katalog gempabumi EHB dan BMKG tahun 1961-2019. Energi gempabumi dihitung dengan mengkonversikan nilai momen seismik ke dalam energi fisis gempabumi. Sedangkan nilai momen seismik didapatkan dari konversi magnitudo gempabumi. Nilai periode ulang didapatkan dengan membagi nilai slip rata-rata terhadap sliprate. Berdasarkan hasil pengolahan data yang dilakukan di 6 segmen berbeda, yaitu Segmen Kuleana, Pewusai, Matano, Pamsoa, Ballawai, dan Garessa masingmasing memiliki nilai potensi magnitudo maksimum yang sedikit berbeda dengan magnitudo maksimum yang dikeluarkan PUSGEN. Semakin besar potensi magnitudo maksimumnya, maka semakin lama pula potensi gempa tersebut akan kembali berulang.
\end{abstract}

Kata Kunci: Energi Kumulatif; Energi Seismik; gempabumi; periode ulang.

\begin{abstract}
The seismic activity of Matano Fault is very high and some of them felt by the humans and causing damage to the surrounding area. Identification of earthquake activity by knowing the amount of energy released in the 6 active segments of Matano fault is needed for earthquake mitigation planning. Estimating of earthquake return period also determined that will occur with the possibility of energy that will be released by the earthquake in the future. The EHB and BMKG earthquake catalogues data compilation of 1961-2019 is used in this reasearch. The earthquake energy is calculated by converting the seismic moment Mo into the physical energy of earthquakes. While the seismic moment Mo is obtained by the earthquake magnitudo conversion. The return period value is calculated by dividing the average slip by the sliprate. Based on the results of data processing carried out in 6 different segments: the Kuleana, Pewusai, Matano, Pamsoa, Ballawai, and Garessa Segments, all of them has a maximum magnitudo potential value that is slightly different from the maximum magnitudo issued by PUSGEN. Earthquake return period has longer when maximum magnitudo potential has greater from the segments.
\end{abstract}

Keywords: Cumulative Energy; Earthquake; Seismic Energy; Return Period of the Earthquake. 


\section{Pendahuluan}

Sesar Matano terbentang mulai dari Sulawesi Tengah bagian Selatan hingga Teluk Tolo, yang merupakan bagian lengan tenggara Sulawesi (Gambar 1). Secara geologi, Patahan Matano memiliki struktur yang bergerak geser mengiri (left lateral) dan telah aktif sejak zaman kuarter (Bellier dkk., 2006). Sesar ini terbagi menjadi 6 segmen yaitu Segmen Kuleana, Pewusai, Matano, Pamsoa, Ballawai, dan. Geressa. Struktur patahan Matano sangat kompleks, sehingga diperlukan adanya studi lebih lanjut untuk mitigasi bencana gempabumi.

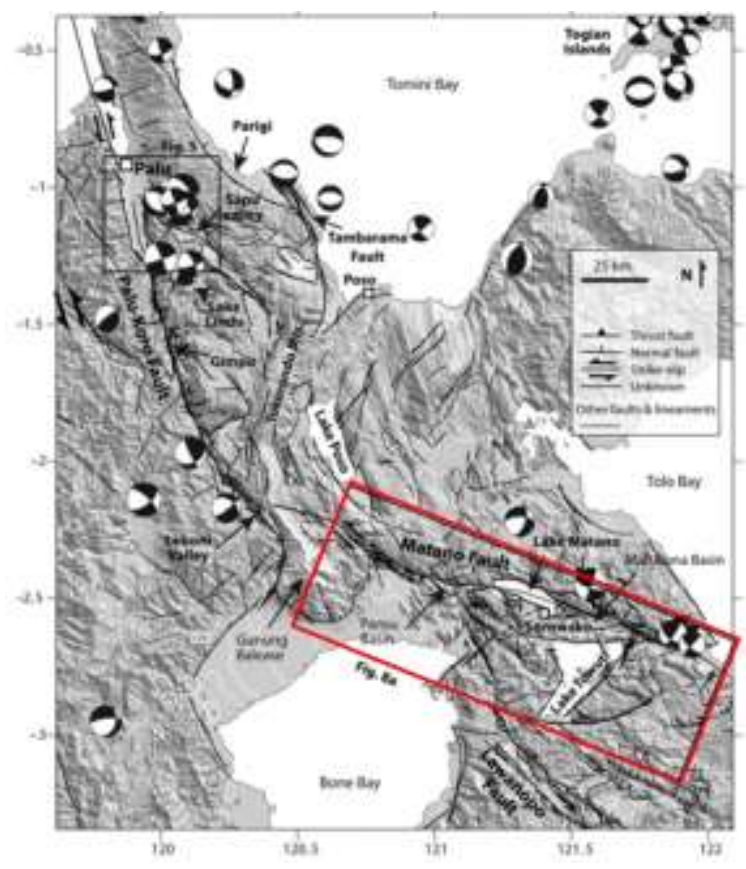

Gambar 1. Peta Sesar aktif di Sulawesi Tengah dan Sekitarnya (Watkinson dan Hall, 2016).

Patahan Matano dibatasi oleh garis kotak merah.

Aspek penting pada aktivitas kegempaan yaitu penjumlahan momen seismik/ energi kumulatif untuk masing - masing gempabumi dalam interval waktu yang terbatas dapat digunakan untuk memperkirakan tingkat slip pada suatu patahan (Brune, 1961). Seismologist bisa mengetahui besar energi yang dilepaskan ketika terjadi gempabumi dengan melakukan konversi magnitudo terhadap energi dan sebagai implementasi rencana tanggap bencana sebagai kunci pembuatan katalog gempabumi (Picozzi dkk., 2019).

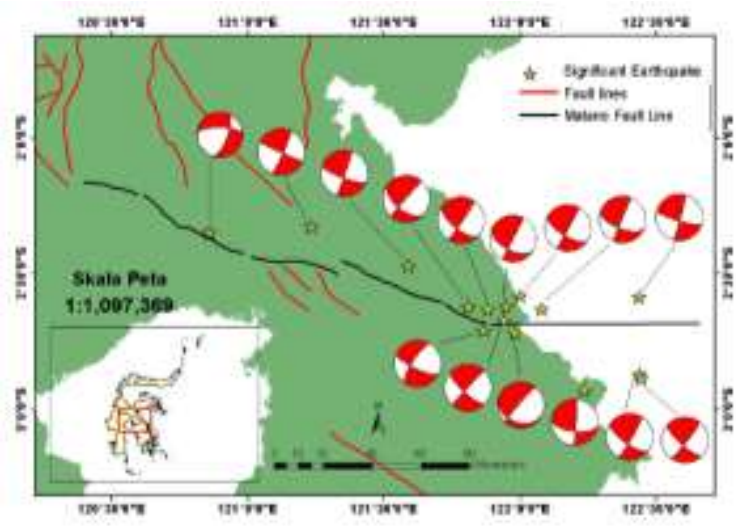

Gambar 2. Mekanisme fokal di 6 segmen Patahan Matano menunjukkan struktur yang bergerak geser mengiri (left lateral).

Karakteristik pergerakan tiap segmen di Patahan Matano dapat dilihat pada Gambar 2. Pergerakan patahan dapat diketahui dari sebaran mekanisme fokal yang diperoleh saat pelepasan energi gempabumi yang diterima seismograf (kompresi/ dilatasi). Gambar 2 menunjukkan sebaran mekanisme fokal dengan gerakan geser mengiri (left lateral) di tiap segmen, sesuai dengan arah pergerakan Patahan Matano secara makro.

Penelitian ini bertujuan untuk mengetahui besarnya energi yang dilepaskan oleh Patahan Matano di setiap segmennya dan estimasi periode ulang gempabumi disertai kemungkinan energi yang akan dilepaskan oleh gempabumi di masa yang akan datang.

\section{Hubungan Magnitudo, Energi Gempabumi dan Patahan}

Besar kecilnya sebuah gempa dapat dinyatakan dalam sebuah kuantitas fisika yang dikenal dengan momen seismik (Hanks dan Kanamori, 1979) mendefinisikan momen seismik skalar (Mo) sebagai,

$$
M o=\mu \bar{D} A
$$

dimana momen seismik (Mo) dinyatakan dalam $\mathrm{Nm}$, rigiditas $(\mu)$ dalam $\mathrm{Nm}^{-2}$, slip rata-rata $\left(\mathrm{D}^{-}\right)$dalam meter dan rupture area (A) dalam $\mathrm{m}^{2}$. 
hubungan antara momen seismik (Mo) dengan beberapa jenis magnitudo (Ms, mb, $\mathrm{Ml})$.

$$
\log M o=1,0 M s+12,2, M s \leq 6,4
$$

$\log M o=1,5 m b+9,0,3,8<m b \leq 5,2$

$\log M o=1,5 M l+8,7,3,6<M l \leq 5,0$

Momen seismik dikonversi ke dalam Magnitudo Momen (Mw) yang tidak mengalami saturasi pada skala tertentu, sebagai:

$$
M w=2 / 3 \log M o-6,0
$$

Wells dan Coppersmith mempelajari hubungan magnitudo terhadap panjang, lebar dan luas rupture secara statistik dan membaginya berdasarkan mekanisme sumbernya yaitu strike slip, reverse dan normal.

$M=4,49+1,49 \times \log R L D$

$M=4,37+1,95 \times \log R W$

$M=4,33+0,90 \times \log R A$

Persamaan (6), (7) dan (8) menunjukkan hubungan antara magnitudo dengan panjang, lebar dan luas rupture gempa. $M$ merepresentasikan magnitudo gempa (Mw), RLD merupakan representasi dari panjang subsurface rupture dalam $\mathrm{km}, R W$ merupakan lebar downdip rupture dalam $\mathrm{km}$ dan $R A$ adalah rupture area dalam $\mathrm{km}^{2}$.

Karakteristik gempabumi dengan kekuatan dan interval periode ulang (Suzuki dan Ozaka, 1994), dihasilkan model seperti Gambar 3. Teori ini menggambarkan bahwa akumulasi energi terjadi karena interaksi pergerakan lempeng. Pada saat akumulasi energi mencapai batas maksimalnya, gempabumi terjadi karena pecahnya lempeng, dan energi dilepaskan sebagai gempabumi. Ada interval waktu sebelum terjadi gempa selanjutnya dimana batuan sedang menahan energi hingga mencapai titik jenuhnya. Siklus ini terus berulang, sehingga biasa disebut periode ulang gempabumi.

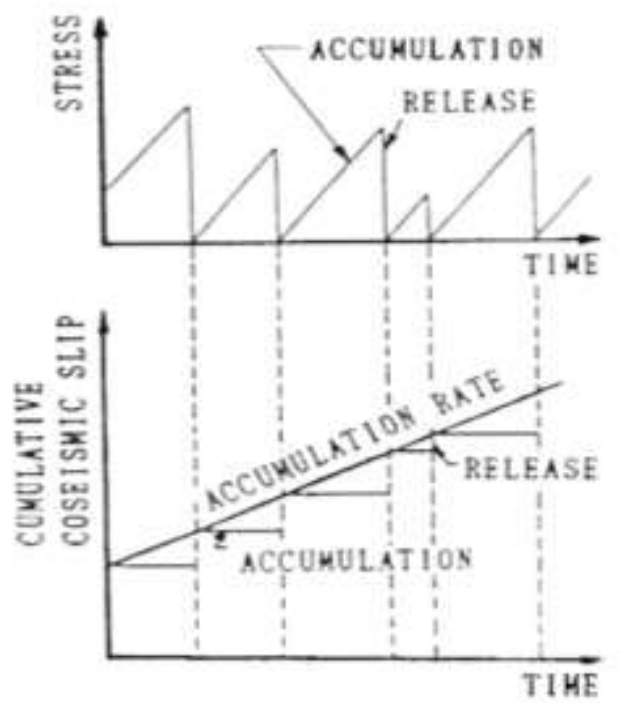

Gambar 3. Grafik model stress dan pergerakan kumulatif patahan terhadap waktu (Suzuki dan Ozaka, 1994).

Energi seismik sebagai dasar penentuan energi seismik kumulatif, dapat dihitung menggunakan persamaan sebagai berikut:

$E s=M o .1 .6 \times 10^{-5}$

dimana Es adalah energi seismik dalam Joule.

\section{Metode Penelitian}

Penelitian ini menggunakan data gempabumi dari katalog EHB dan BMKG selama periode 1961 - 2019 di Patahan Matano $\left(2^{\circ} \mathrm{LS}-3^{\circ} \mathrm{LS}\right.$, dan $120,56^{\circ} \mathrm{BT}-$ $\left.123,23^{\circ} \mathrm{BT}\right)$.

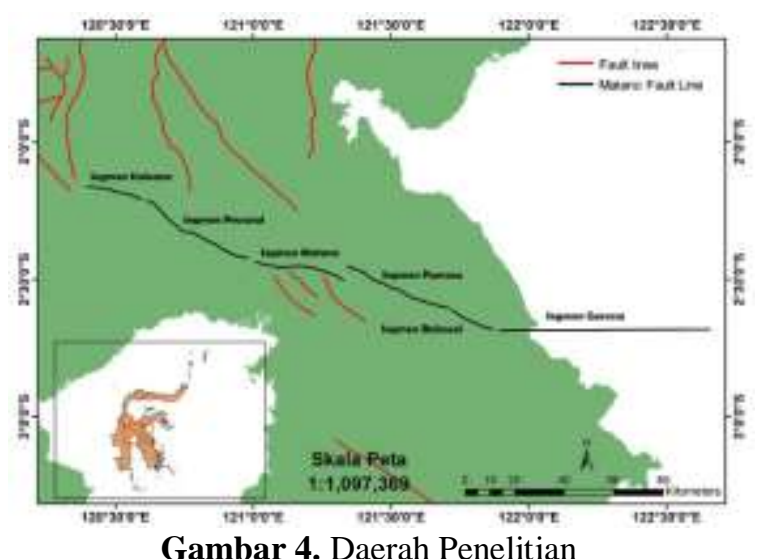

Gambar 4. Daerah Penelitian 
Selama periode 58 tahun terakhir telah terjadi 8 gempabumi signifikan dengan $\mathrm{Mw}$ $>$ 6. Data dianalisis menggunakan metode statistik deskriptif dan visual dengan penyajian peta dan grafik. Berikut langkah prosedur penelitian:

1. Mengumpulkan katalog gempabumi EBH dan BMKG (1961 - 2019)

2. Melakukan penyaringan (filtering) data gempabumi lokal di sepanjang Sesar Matano (gempa dangkal)

3. Memisahkan data tiap segmen Sesar Matano

4. Menghitung momen seismik, energi kumulatif dan slip rata-rata

5. Menghitung periode ulang

6. Membuat peta dengan menggunakan GMT.

7. Membuat analisa pembahasan

8. Kesimpulan

\section{Hasil dan Pembahasan}

\section{Energi Seismik Kumulatif}

Energi seismik merupakan bagian dari energi potensial yang dilepaskan selama gempabumi, dikonversi menjadi gelombang seismik elastis dan merambat dari sumber gempa melalui bumi, menyebabkan adanya pergerakan tanah, sehingga energi seismik kumulatif adalah total dari energi seismik yang dilepaskan selama periode dan segmen tertentu.

\section{Segmen Kuleana}

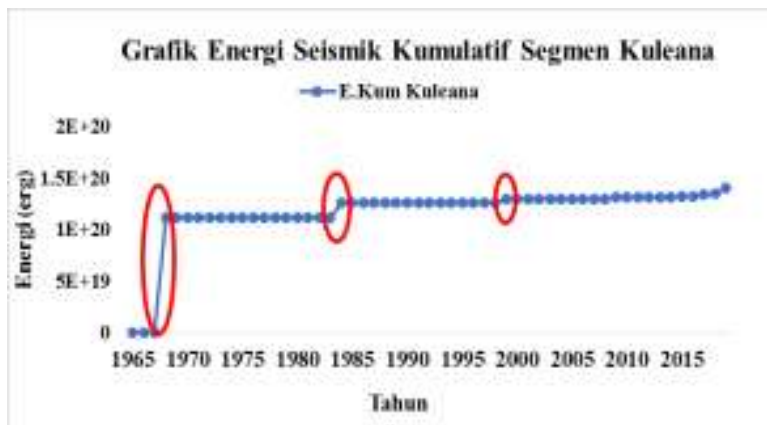

Gambar 5. Energi kumulatif gempabumi di Segmen Kuleana periode 1961 - 2019.

Selama kurang lebih 58 tahun (1961 2019) sedikitnya 45 gempabumi sudah terjadi di Segmen Kuleana dan tercatat ada 3 kali fase coseismic yaitu pada tahun 1968, 1984 dan 1999. Fase coseismic merupakan fase gempabumi dimana terjadi pelepasan energi yang relatif besar di segmen tersebut.

Selama kurang lebih 58 tahun, energi akibat aktifitas gempabumi yang sudah dilepaskan di Segmen Kuleana sebesar 1,4 x $10^{20}$ erg. Berdasarkan penelitian yang dilakukan oleh tim PUSGEN, Segmen Kuleana memiliki potensi gempabumi dengan magnitudo maksimum sebesar $\mathrm{Mw}$ 6,6 atau setara dengan 5,01 x $10^{21} \mathrm{erg}$. Sehingga diperkirakan sisa energi yang masih tersimpan di Segmen Kuleana sebesar 4,8 $\times 10^{21}$ erg atau setara dengan kekuatan gempabumi Mw 6,5.

\section{Segmen Pewusai}

Selama kurang lebih 42 tahun (1977 2019) sedikitnya 139 gempabumi sudah terjadi di Segmen Pewusai dan tercatat ada 2 kali fase coseismic yaitu pada tahun 1982 dan 2017.

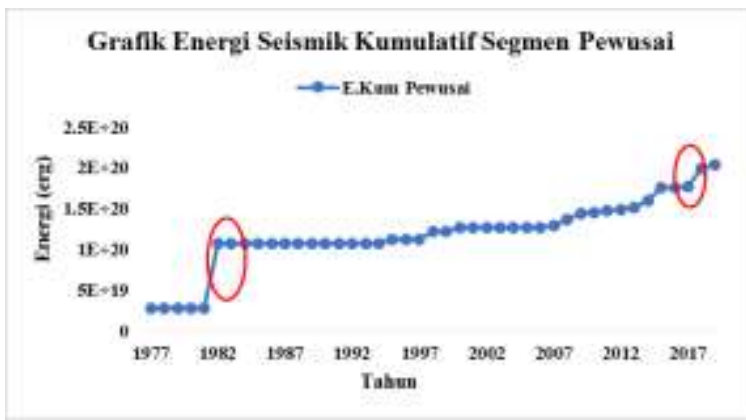

Gambar 6. Energi kumulatif gempabumi di Segmen Pewusai periode 1977 - 2019.

Selama kurang lebih 42 tahun, energi akibat aktifitas gempabumi yang sudah dilepaskan di Segmen Pewusai sebesar $2,04 \times 10^{20}$ erg. Berdasarkan penelitian yang dilakukan oleh tim PUSGEN, Segmen Pewusai memiliki potensi gempabumi dengan magnitudo maksimum sebesar Mw 6,9 atau setara dengan 1,41 x $10^{22} \mathrm{erg}$. Sehingga diperkirakan sisa energi yang masih tersimpan di Segmen Pewusai sebesar $1,39 \times 10^{22}$ erg atau setara dengan kekuatan gempabumi Mw 6,8. 


\section{Segmen Matano}

Selama kurang lebih 24 tahun (1995 2019) sedikitnya 109 gempabumi sudah terjadi di Segmen Matano dan tercatat ada 2 kali fase coseismic yaitu pada tahun 2009 dan 2011.

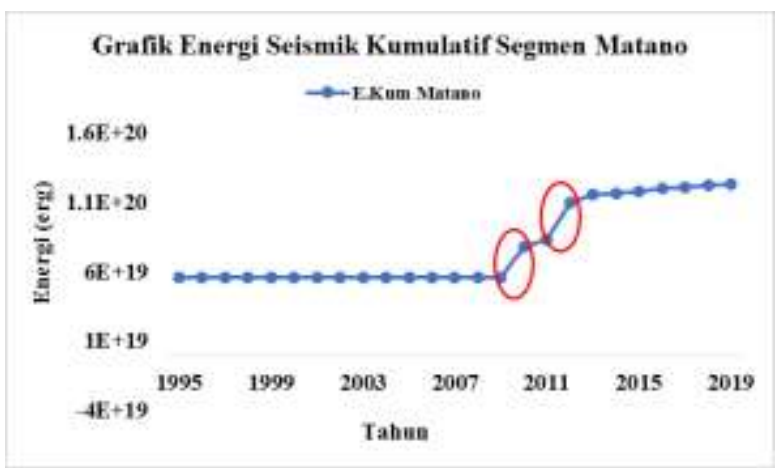

Gambar 7. Energi kumulatif gempabumi di Segmen Matano periode 1995 - 2019.

Selama kurang lebih 24 tahun, energi akibat aktifitas gempabumi yang sudah dilepaskan di Segmen Matano sebesar 1,23 x $10^{20}$ erg. Berdasarkan penelitian yang dilakukan oleh tim PUSGEN, Segmen Matano memiliki potensi gempabumi dengan magnitudo maksimum sebesar $\mathrm{Mw}$ 6,8 atau setara dengan $1 \times 10^{22}$ erg. Sehingga diperkirakan sisa energi yang masih tersimpan di Segmen Pewusai sebesar $9,87 \times 10^{21}$ erg atau setara dengan kekuatan gempabumi Mw 6,7.

\section{Segmen Pamsoa}

Selama kurang lebih 35 tahun (1984 2019) sedikitnya 85 gempabumi sudah terjadi di Segmen Pamsoa dan tercatat ada 1 kali fase coseismic yaitu pada tahun 2010 .

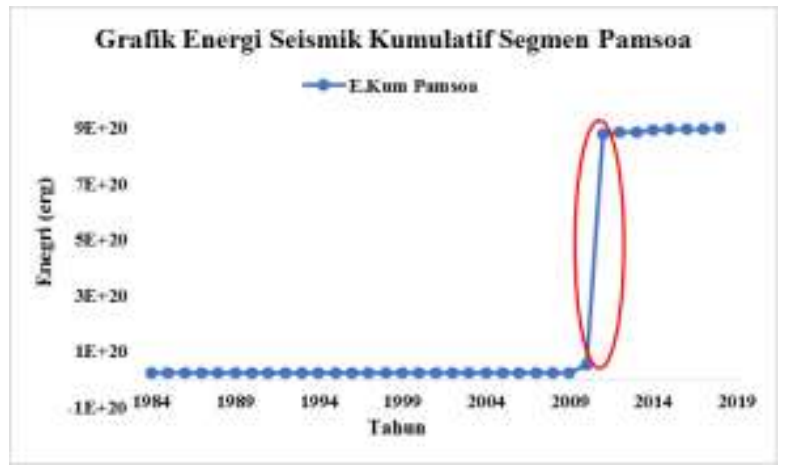

Gambar 8. Energi kumulatif gempabumi di Segmen Pamsoa periode 1984 - 2019.

(C) 2020 Dept. of Geophysics Hasanuddin University
Selama kurang lebih 35 tahun, energi akibat aktifitas gempabumi yang sudah dilepaskan di Segmen Pamsoa sebesar 9,25 $\mathrm{x} 10^{22} \mathrm{erg}$. Berdasarkan penelitian yang dilakukan oleh tim PUSGEN, Segmen Pamsoa memiliki potensi gempabumi dengan magnitudo maksimum sebesar $\mathrm{Mw}$ 6,9 atau setara dengan $1,41 \times 10^{22} \mathrm{erg}$. Sehingga diperkirakan sisa energi yang masih tersimpan di Segmen Pamsoa sebesar $1,39 \times 10^{22}$ erg atau setara dengan kekuatan gempabumi Mw 6,8.

\section{Segmen Ballawai}

Selama kurang lebih 16 tahun (2000 2016) sedikitnya 28 gempabumi sudah terjadi di Segmen Ballawai dan tercatat ada 2 kali fase coseismic yaitu pada tahun 2009 dan 2011.

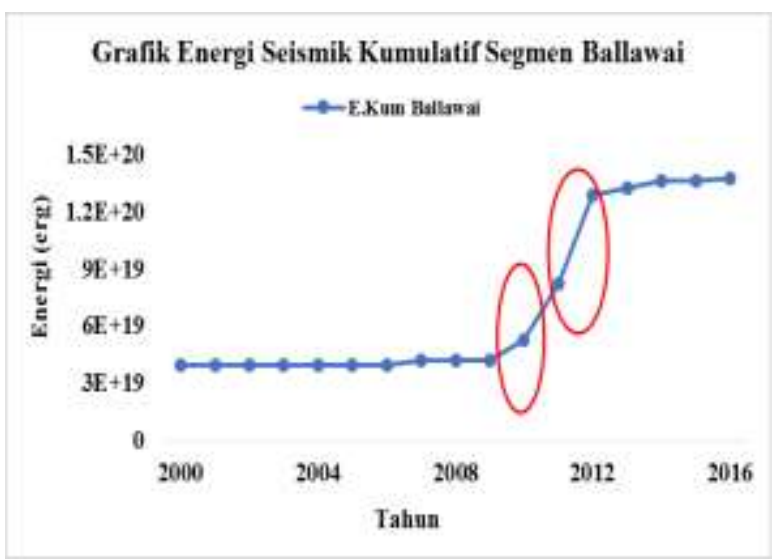

Gambar 9. Energi kumulatif gempabumi di Segmen Ballawai periode 2000 - 2016.

Selama kurang lebih 16 tahun, energi akibat aktifitas gempabumi yang sudah dilepaskan di Segmen Ballawai sebesar $1,37 \times 10^{20}$ erg. Berdasarkan penelitian yang dilakukan oleh tim PUSGEN, Segmen Ballawai memiliki potensi gempabumi dengan magnitudo maksimum sebesar Mw 6,7 atau setara dengan 7,07 x $10^{21} \mathrm{erg}$. Sehingga diperkirakan sisa energi yang masih tersimpan di Segmen Ballawai sebesar $6,9 \times 10^{21}$ erg atau setara dengan kekuatan gempabumi Mw 6,6. 


\section{Segmen Garessa}

Selama kurang lebih 56 tahun (1961 2017) sedikitnya 29 gempabumi sudah terjadi di Segmen Garessa dan tercatat ada 4 kali fase coseismic yaitu pada tahun 1979, 1999, 2011 dan 2013.

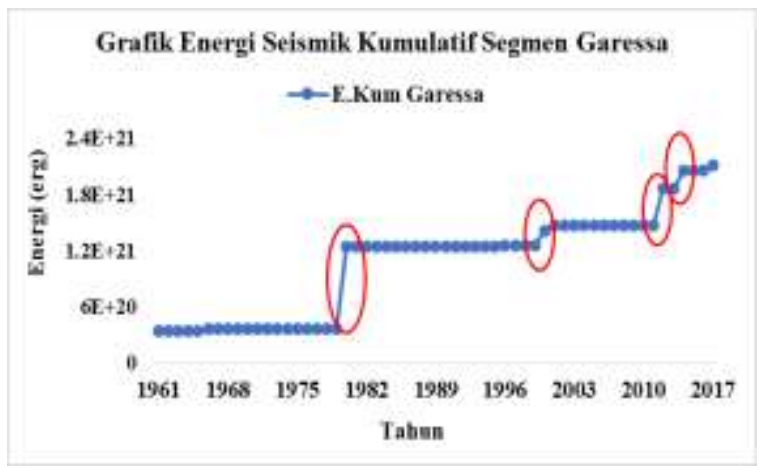

Gambar 10. Energi kumulatif gempabumi di Segmen Garessa periode 1961 - 2017.

Selama kurang lebih 56 tahun, energi akibat aktifitas gempabumi yang sudah dilepaskan di Segmen Garessa sebesar 2,11 $\mathrm{x} 10^{21} \mathrm{erg}$. Berdasarkan penelitian yang sudah dilakukan oleh tim PUSGEN, Segmen Garessa memiliki potensi gempabumi dengan magnitudo maksimum sebesar Mw 7,2 atau setara dengan 3,98 x $10^{22} \mathrm{erg}$. Oleh karena itu, diperkirakan sisa energi yang masih tersimpan di Segmen Garessa sebesar 3,76 × $10^{22}$ erg atau setara dengan kekuatan gempabumi Mw 7,1.

\section{Kondisi Kegempaan dan Periode Ulang Gempabumi}

Berdasarkan rekaman data gempabumi selama periode 1961 - Agustus 2019, ke-6 Segmen tersebut belum pernah terjadi gempabumi dengan magnitudo maksimum yang dikeluarkan oleh tim PUSGEN 2017. Sebanyak 435 kejadian gempabumi merupakan gempa dangkal (Gambar 11), secara rinci terlihat pada Tabel 1. Hal ini menunjukkan bahwa semua Segmen di Patahan Matano beresiko mengakibatkan gempabumi merusak dimana diketahui bahwa struktur daerah yang memiliki danau menunjukkan struktur tersebut cenderung bersifat lunak. Jika terjadi gempa besar dan dangkal maka kekuatan yang dirasakan akan mengalami amplifikasi dan berpotensi merusak bangunan di atasnya.

Tabel 1. Jumlah Gempabumi di 6 Segmen Matano

\begin{tabular}{ccccccc}
\hline Nama Segmen & Kuleana & Pewusai & Matano & Pamsoa & Ballawai & Garessa \\
\hline $\begin{array}{c}\text { Jumlah } \\
\begin{array}{c}\text { fempabumi } \\
\text { Dangkal }\end{array}\end{array}$ & 45 & 139 & 109 & 85 & 28 & 29 \\
\hline
\end{tabular}

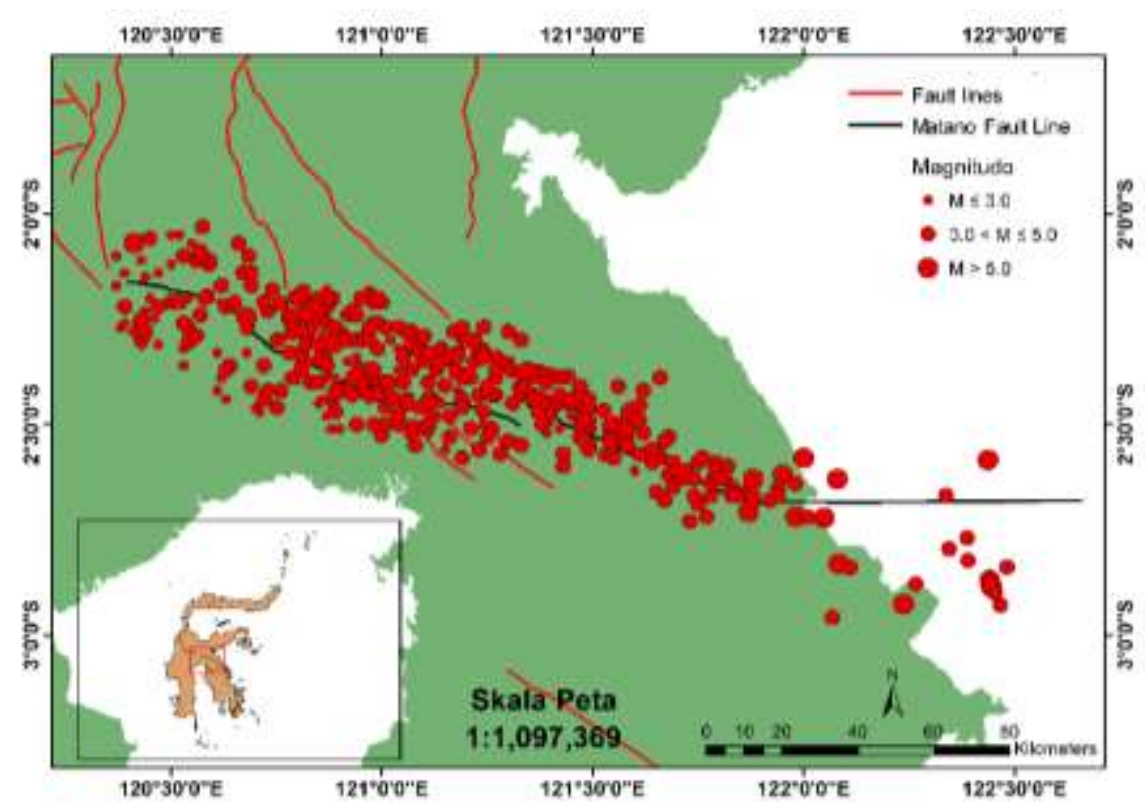

Gambar 11. Peta kegempaan di sekitar Patahan Matano periode 1961 hingga Agustus 2019 
Dari penelitian yang dilakukan oleh tim PUSGEN bisa diperoleh nilai slip rata rata masing - masing segmen dan estimasi periode ulang gempabumi di masing masing segmen dengan mengasumsikan bahwa satu periode siklus gempabumi sebagai waktu yang dibutuhkan untuk mencapai nilai dislokasi sebesar slip rata rata. Nilai periode ulang ini juga berbeda beda karena dipengaruhi oleh luas sesar (fault area) masing - masing segmen.

Tabel 2. Periode ulang gempabumi signifikan di 6 segmen

\begin{tabular}{cccccccc}
\hline \multirow{2}{*}{ Segmen } & Mw & \multicolumn{3}{c}{ PUSGEN 2017 } & \multicolumn{2}{c}{ Wells \& Coppersmith (1994) } \\
\cline { 3 - 8 } & $\begin{array}{c}\text { Area } \\
\left(\mathrm{Km}^{2}\right)\end{array}$ & $\begin{array}{c}\text { Slip rata }- \\
\text { rata }(\mathrm{m})\end{array}$ & $\begin{array}{c}\text { Periode Ulang } \\
(\text { Tahun })\end{array}$ & $\begin{array}{c}\text { Area } \\
\left(\mathrm{Km}^{2}\right)\end{array}$ & $\begin{array}{c}\text { Slip rata }- \\
\text { rata }(\mathrm{m})\end{array}$ & $\begin{array}{c}\text { Periode Ulang } \\
(\text { Tahun })\end{array}$ \\
\hline Kuleana & 6,6 & 330 & 0,90 & 129,27 & 332,82 & 0,89 & 128,17 \\
\hline Pewusai & 6,9 & 975,81 & 0,86 & 123,21 & 717,06 & 1,17 & 167,67 \\
\hline Matano & 6,8 & 525 & 1,13 & 162,12 & 555,19 & 1,07 & 153,31 \\
\hline Pamsoa & 6,9 & 660 & 1,27 & 182,16 & 717,06 & 1,17 & 167,67 \\
\hline Ballawai & 6,7 & 390 & 1,08 & 154,50 & 429,86 & 0,98 & 140,01 \\
\hline Garessa & 7,2 & 1200,18 & 1,97 & 282,34 & 1544,85 & 1,53 & 219,34 \\
\hline
\end{tabular}

Berdasarkan tabel di atas, terlihat adanya perbedaan nilai periode ulang antara data PUSGEN dengan perhitungan periode ulang menggunakan persamaan Wells dan Coppersmith (1994), dimana nilai periode ulang dengan data PUSGEN cenderung lebih besar/ lama daripada nilai yang diperoleh dengan persamaan Wells dan Coppersmith (1994). Hal ini disebabkan oleh perbedaan luasan patahan (fault area) masing-masing segmen serta histori dip fault di daerah Matano dan sekitarnya cenderung sedikit sehingga data yang digunakan terbatas. Akibatnya memberikan luasan fault yang lebih besar daripada luasan dengan persamaan Wells dan Coppersmith (1994). Dari perhitungan di atas terlihat bahwa semakin besar potensi magnitudo maksimum yang akan terjadi, maka dibutuhkan waktu lama gempa tersebut akan berulang.

\section{Kesimpulan}

Berdasarkan hasil pengolahan data yang dilakukan 6 segmen di Sesar Matano, yaitu Segmen Kuleana, Pewusai, Matano, Pamsoa, Ballawai, dan Garessa, dapat disimpulkan:

1. Secara keseluruhan untuk segmen pada Sesar Matano memiliki Magnitudo maksimum dengan interval $\mathrm{Mw}$ 6,6 7,2 dengan durasi periode ulang 123 sampai 282 tahun.

2. Energi yang masih tersimpan pada semua segmen di Sesar Matano cenderung masih tinggi dan berpotensi gempa dengan energi sebesar $4,8 \times 10^{21}$ hingga $3,76 \times 10^{22}$ erg yang setara dengan Mw 6,5-7,1.

3. Magnitudo sebanding dengan waku, sehingga semakin besar potensi magnitudo maksimum pada suatu segmen, semakin lama pula potensi gempa tersebut akan berulang.

\section{Ucapan Terima Kasih}

Ucapan terima kasih ditujukan kepada BMKG dan ISC atas penyedia data dan rekan - rekan yang telah menambah diskusi atas tulisan ini, serta pihak penyelenggara seminar yang telah memberikan kesempatan dan masukan agar tulisan ini menjadi lebih baik.

\section{Saran}

Pengembangan penelitian lanjutan dapat diintegrasikan dengan metode seismik lainnya. 


\section{Daftar Pustaka}

Bellier, O., Se brier, M., Seward, D., Beaudouin, T., Villeneuve, M. dan Putranto, E. 2006. Fission track and fault kinematics analyses for new insight into the Late Cenozoic tectonic regime changes in West-Central Sulawesi (Indonesia). Tectonophysics, 413, 201 - 220. 42(3), pp.164 - 177.

Brune, James N. 1961. Seismic Moment, Seismicity, and Rate of Slip along Major Fault Zones. Journal of Geophysical Research. 73, pp.777 784.

Hanks, T.C, dan Kanamori, H. 1979. A moment magnitudo scale. Journal of Geophysical Research. 84(5), pp.2348 -2350 .

Picozzi M., D. Bindi, D. Spallarossa, A. Oth., D. Di Giacomo dan A. Zollo. 2019. Moment and energy magnitudos: diversity of views on earthquake shaking potential and earthquake statistics. Geophys. J. Int. GJI Seismology. 216, pp.1245 - 1259.

Pusat Studi Gempa Nasional (PUSGEN). 2017. Peta Sumber dan Bahaya Gempa Indonesia Tahun 2017. Bandung: Pusat Penelitian dan Pengembangan
Perumahan dan Permukiman, Kementrian PUPR. ISBN: 978-6025489-01-3.

Suzuki, Michi-to dan Ozaka, Y. 1994. Seismic Risk Analysis Based on Strain Energy Accumulation in Focal Region. Journal of Research of the National Institute of Standards and Technology. 99, pp.421 - 434.

Watkinson, Ian M dan Hall, R. 2016. Fault systems of the eastern Indonesian triple junction: evaluation of Quaternary activity and implications for seismic hazards. Geohazards in Indonesia: Earth Science for Disaster Risk Reduction Geological Society. https://doi.org/10.1144/SP441.8.

Wells, D.L. dan Coppersmith K.J. 1994. New Empirical Relationships among Magnitudo, Rupture Length, Rupture width, Rupture Area, and Surface Displacement. Bulletin of the Seismological Society of America. 84, pp.974 - 1002 .

*) Artikel ini telah dipresentasikan di Seminar Nasional Geofisika 2019 yang dilaksakan oleh Dept. Geofisika FMIPA Universitas Hasanuddin di Science Building FMIPA Universitas Hasanuddin pada tanggal 26 Oktober 2019. 